\title{
MANAGEMENT OF WOUND INFECTION AFTER LUMBAR ARTHRODESIS MAINTAINING THE INSTRUMENTATION
}

\author{
MANEJO DA INFECÇÃO DE FERIDA OPERATÓRIA APÓS ARTRODESE LOMBAR \\ MANTENDO A INSTRUMENTAÇÃO
}

\section{MANEJO DE LA INFECCIÓN OPERATORIA DESPUÉS DE ARTRODESIS LUMBAR SIN REMOVER LA INSTRUMENTACIÓN}

Asdrubal Falavigna', Orlando Righesso ${ }^{1}$, Alisson Roberto Teles ${ }^{1}$, Pedro Guarise da Silva ${ }^{1}$

\begin{abstract}
Objective: To determinate whether a surgical protocol with immediate extensive debridement, closed irrigation system and antibiotic therapy would be effective to achieve healing of deep wound infection without removing the instrumentation. Methods: Prospective cohort study with 19 patients presenting degenerative spinal stenosis or degenerative spondylolisthesis, who developed infection after posterior lumbar arthrodesis. The diagnosis was confirmed by a microbial culture from subfascial lumbar fluid and/or blood. Patients were treated with a protocol of wound exploration, extensive flushing and debridement, placement of a closed irrigation system that was maintained for five days and intravenous antibiotics. The instrumentation system was not removed. Results: Mean age was $59.31( \pm 13.17)$ years old and most patients were female $(94.7 \%$; 18/19). The mean period for the identification of the infection was 2 weeks and $57.9 \%$ underwent a single wound exploration. White blood count, erythrocyte sedimentation rate and C-reactive protein showed a significant decrease post-treatment when compared to pre-treatment values. A significant reduction of erythrocyte sedimentation rate and C-reactive protein was also observed at the final evaluation. No laboratory test was useful to predict the need for more than one debridement. Conclusion: Patients with wound infection after instrumentation can be treated without removal of the instrumentation through wound exploration, extensive flushing, debridement of necrotic tissue, closed irrigation system during 5 days and proper antibiotic therapy. The blood tests were not useful to predict surgical re-interventions.
\end{abstract}

Keywords: Surgical wound infection; Chronic disease; C-Reactive protein; Leukocyte count; Erythrocyte count.

\section{RESUMO}

Objetivo: Determinar se um protocolo cirúrgico de desbridamento extenso imediato, sistema de irrigação fechado e antibioticoterapia seria eficaz para alcançar a resolução da infecção profunda da ferida sem remover a instrumentação. Métodos: Estudo prospectivo de coorte com 19 pacientes com estenose espinhal degenerativa ou espondilolistese degenerativa, que desenvolveram infecção após artrodese lombar posterior. O diagnóstico foi confirmado por uma cultura microbiana de fluido subfascial lombar e/ou sangue. Os pacientes foram tratados com um protocolo de exploração de ferida, irrigação extensa e desbridamento, colocação de um sistema de irrigação fechado que foi mantido durante cinco dias e antibióticos por via intravenosa. O sistema de instrumentação não foi removido. Resultados: A média de idade foi de 59,31 anos ( $\pm 13,17)$ e a maioria dos pacientes era do sexo feminino (94,7\%; 18/19). O tempo médio para a identificação da infecção foi de duas semanas e 57,9\% foram submetidos a apenas uma exploração da ferida. A contagem de eritrócitos, a sedimentação de eritrócitos e a proteína C-reativa mostraram diminuição significativa após o tratamento. Na avaliação final, também foi obsenvada redução significativa da sedimentação de eritrócitos e de proteína C-reativa. Nenhum exame laboratorial foi útil para prever a necessidade de mais do que um desbridamento. Conclusão: Os pacientes com infecção da ferida após a instrumentação podem ser tratados sem a remoção da instrumentação por meio da exploração da ferida, irrigação intensa, desbridamento de tecidos necróticos, sistema de irrigação fechado mantido por 5 dias e antibioticoterapia adequada. Os exames de sangue não foram úteis para prever a revisão cirúrgica.

Descritores: Infecção da ferida operatória; Doença crônica; Proteína C-reativa; Contagem de leucócitos; Contagem de eritrócitos.

\section{RESUMEN}

Objetivo: Determinar si un protocolo quirúrgico de desbridamiento extenso inmediato, sistema de irrigación cerrado y antibioticoterapia seria eficaz para alcanzar la resolución de la infección profunda de la herida sin remover la instrumentación. Métodos. Estudio prospectivo de corte con 19 pacientes con estenosis espinal degenerativa o espondilolistesis degenerativa, que desarrollaron infección después de artrodesis lumbar posterior. El diagnóstico se confirmó por un cultivo microbiano de fluido subfascial lumbar y/o sangre. Los pacientes fueron tratados con un protocolo de exploración de la herida, lavado profuso y desbridamiento, la colocación de un sistema de irrigación cerrado que se mantuvo durante cinco días y antibióticos por vía intravenosa. El sistema de instrumentación no ha sido retirado. Resultados. La media de edad promedio fue de 59,31 ( $\pm 13,17)$ años y la mayoría de los pacientes eran mujeres (94,7\%; 18/19). El tiempo medio para la identificación de la infección fue de 2 semanas y el 57,9\% se sometió a una única exploración de la herida. Recuento de glóbulos blancos, velocidad de sedimentación globular y la proteína C-reactiva mostraron una disminución significativa después del tratamiento en comparación con los valores pre-tratamiento. En la evaluación final también se observó una reducción significativa de la tasa de sedimentación de eritrocitos y de proteína C-reactiva. Ningún análisis de laboratorio fue útil para predecir la necesidad de más que un desbridamiento. Conclusión. Pacientes con infección de la herida después de la instrumentación se pueden tratar sin la remoción de la instrumentación a través de la exploración de la herida, lavado extensivo, desbridamiento de tejido necrótico, sistema de irrigación cerrado durante 5 días y antibioticoterapia adecuada. Los análisis de sangre no fueron útiles para predecir reintervenciones quirúrgicas.

Descriptores: Infección de herida operatoria; Enfermedad crónica; Proteína C-reactiva; Recuento de leucocitos; Recuento de eritrocitos.

1. Universidade de Caxias do Sul, Caxias do Sul, RS, Brazil.

Work done at the Universidade de Caxias do Sul, Faculdade de Medicina, Caxias do Sul, RS, Brasil.

Correspondence: Faculdade de Medicina da Universidade de Caxias do Sul. Rua General Arcy da Rocha Nóbrega, 401/602. Caxias do Sul, RS, Brazil. 95040-290. asdrubalmd@ gmail.com 


\section{INTRODUCTION}

Deep wound infection (DWI) occurs after instrumented posterior lumbar spinal surgery, despite antibiotic prophylaxis and aseptic techniques. ${ }^{1,2}$ In these cases the incidence of DWI increased from $1.5 \%$, in patients in whom instrumentation was not used, to $6 \%$ in cases in which a fixation system was used, such as pedicular screws and interbody device. ${ }^{2-6}$ Once the patients have a lumbar DWI there is a reduction of a favorable surgical outcome $e^{2,7,8}$ and treatment cost increases. ${ }^{7,9-11}$

The proper treatment of DWI after instrumented spinal fusion surgery is crucial to achieve spinal fusion and a successful outcome. ${ }^{12}$ The principles of treatment are appropriate antibiotic therapy, nutritional support and aggressive debridement. ${ }^{10,13}$ No consensus exists in the literature regarding primary or delayed wound closure, the need or not for a suction-irrigation system and the need to remove the instrumentation. ${ }^{4,5,14-18}$

The purpose of this surgical prospective cohort study was to investigate the efficacy in patients with DWI after instrumented posterior lumbar spinal surgery for degenerative diseases through a protocol with wound exploration, washing, extensive debridement, use of closed irrigation system for five days, appropriate antibiotic therapy and maintaining the instrumentation, as well as to what extent blood tests can predict the need for reintervention.

\section{METHODS}

Patients with a diagnosis of postoperative DWI were selected in a surgical prospective cohort study of patients with lumbar degenerative spinal stenosis and degenerative spondylolisthesis disorders who underwent lumbar spine decompression and instrumented fusion between January 2000 and December 2011. The study was approve by the Istitutional Reviw Board (protocol \# 33708). The instrumentation material used was titanium for pedicle screws and titanium or polyetheretherketone for the interbody device. This surgical cohort is followed systematically as described briefly elsewhere. ${ }^{19}$

All patients were treated and followed by the same surgeons (AF, OR). The patients received antibiotic prophylaxis with cefazoline during the first surgical procedure and aseptic techniques were meticulously implemented during the surgical procedure.

The patients reported lumbar pain combined with fluid leakage from the skin. Usually fever, shaking and hemodynamic stability were associated. The patient was promptly submitted to clinical evaluation and blood samples were collected for analysis of white blood cells (WBC), erythrocyte sedimentation rate (ESR), C-reactive protein (CRP), blood and urine culture. The patient was promptly submitted to surgical intervention and subfascial fluid and tissue was collected for a laboratory culture. The diagnosis of DWI was established after positive bacterial cultures from subfascial fluid and inflammatory tissue.

When there was a clinical suspicion of postoperative infection, patients were submitted to wound exploration for the purpose of extensive washing, collecting material for bacteriological examination, removal of the devitalized bone fragments and necrotic tissue, placement of a continuous irrigation system, and primary wound closure. The instrumentation system was not removed. A closed irrigation system was placed during the surgery and continuously used for 5 days. The same surgical team performed all procedures.

The inflow system catheter of the irrigation system was placed under the fascia in the cephalad portion of the wound. The inflow catheter was continuous irrigated with sterile normal saline, set at a flow of $40 \mathrm{cc} / \mathrm{hour}$. The outflow system consisted of a thoracic drain placed deep in the fascia, and connected to a negative pressure suction device.

Properly targeted intravenous antimicrobial agents were administered during 4 to 6 weeks and then followed by at least 2 weeks of oral antimicrobial therapy. In addition to monitoring the patients' clinical status and temperature, responsiveness to the treatment was regularly accessed through the blood test results of WBC, ESR and CRP, and the culture results of the fluid from the outflow irrigation system before having them removed.
The irrigation system was replaced for another 5 days if the CRP and ESR did not diminish, the clinical symptoms of infection did not improve, or when the irrigation system outflow fluid continued to present positive cultures.

The radiological evaluation of the lumbar spine was performed with plain radiography, flexion-extension radiology and computer tomography $(\mathrm{CT})^{19}$ where the following were analyzed: lumbar lordosis, presence of fusion, displacement of intervertebral device, instability and breakage or displacement of devices before the wound exploration, 30 days, 6 months and at the last evaluation.

The lumbar lordosis was analyzed with the patient in orthostatic position in sagittal neutral lumbar view from the superior border of the first lumbar vertebra to the superior plateau of the sacrum.

Segment instability was defined as a translational displacement of more than $3 \mathrm{~mm}$ in flexion-extension radiology.

The presence of a bone bridge in the lumbar instrumented vertebrae was addressed using CT in coronal and sagittal views at the facet area, transverse process and the interbody space.

\section{Statistical analyses}

Statistical analyses were conducted with SPSS 20. Categorical variables were presented as number and percentage. Continuous variables were presented as mean and standard deviation or median and interquartile interval, depending on distribution. Paired analyses were performed with a paired Student $t$ test. Bivariate comparisons were performed with an independent Student t test. Confidence intervals of $95 \%(\mathrm{Cl} 95 \%)$ were calculated. ROC (receiver operating characteristics) curve analyses were conducted in order to verify the discrimination capacity of laboratory elements in predicting the need for more than one debridement. The area under the ROC curve higher than 0.80 or 0.90 indicates appropriate levels of discrimination in a clinical context; the closer the area is to 0.50, the higher the probability of random results in discrimination.

\section{RESULTS}

During the last decade, among the 390 patients with lumbar spinal stenosis and degenerative spondylolisthesis who underwent decompression and instrumented fusion (4.87\%), 19 patients presented postoperative DWI

The baseline characteristics of the infected patients are shown in Table 1. The mean age of the sample was $59.31( \pm 13.17)$ years old and most of them were women $(94.7 \% ; 18 / 19)$. Degenerative spinal stenosis $(57.9 \%, 11 / 19)$ and degenerative spondylolisthesis $(42.1 \%$, $8 / 19$ ) were the primary pathology. Comorbidity for infection was observed in $68.4 \%$ (13/19) of the sample, such as obesity in 5 cases, systemic arterial hypertension in two cases, diabetes mellitus in nine cases, and chronic corticosteroid use in one case. The number of fused levels varied from 1 to 14 (median = 2; P25: 2 - P75: 4). The symptoms of wound infection were observed in the first 2 weeks after the primary surgery in 8 (57.1\%) patients (median 2; P25: 1 - P75:3). The number of interventions was one debridement in 11 patients $(57.8 \%)$, two in three patients (15.7\%) and more than two in 5 patients (26.3\%). The follow-up varied from 6 to 72 months (mean $45.63 \pm 20.27$ ).

The most common bacteria identified in cultures was Staphilococcus aureus $(68.4 \%, 13 / 19)$ and polymicrobial infection was identified in $15.8 \%(3 / 19)$ patients. (Table 2$)$

Paired analyses demonstrated a trend to normality of the laboratory exams after 6 weeks and the final evaluation of DWI treatment. (Table 3) During the first 6 weeks, a mean value reduction was observed of 2828.94 in WBC (sd: 4128.19; C195\%: 839.21 - 4818.67; $\mathrm{P}=0.008$ ), 38.05 in ESR (sd: 21.11; Cl95\%: 27.87 - 48.23; $\mathrm{P}<0.0001$ ) and 66.66 in CRP (sd: 41.21; Cl95\%: 46.80 - 86.53; $P<0.0001$ ). In the time elapsed between 6 weeks post-treatment and the final evaluation, a mean difference reduction was observed of 2230.0 in WBC (sd: 49.27.55; Cl95\%: -145.00 - 46.05; P = 0.064), 36.73 in ESR (sd: 26.70; Cl95\%: 23.86 - 49.60; $P<0.0001$ ) and 25.50 in CRP (sd: 23.28; Cl95\%: 14.28 - 36.72; $P<0.0001$ ). (Figures 1 to 3 )

There were no laboratory tests for WBC, ESR or CRP that could 
Table 1. Baseline characteristics of the patients with DWI.

\begin{tabular}{|c|c|c|c|c|c|c|c|c|c|c|}
\hline Case & Gender & Age & Pathology & $\begin{array}{c}\begin{array}{c}\text { Associated } \\
\text { factors }\end{array} \\
\end{array}$ & $\begin{array}{l}\begin{array}{l}\text { Fusion } \\
\text { levels }\end{array} \\
\end{array}$ & $\begin{array}{c}\text { Time for onset } \\
\text { (weeks) }\end{array}$ & $\begin{array}{c}\text { Number of } \\
\text { debridements }\end{array}$ & Organism & $\begin{array}{c}\text { Antibiotics } \\
\text { (weeks) }\end{array}$ & $\begin{array}{c}\text { Follow-up period } \\
\text { (months) }\end{array}$ \\
\hline 2 & $\mathrm{~F}$ & 28 & SS & DM & L4-S1 & 5 & 1 & Staphylococus Aureus & $3 \mathrm{IV}$ & 64 \\
\hline 5 & $\mathrm{~F}$ & 70 & $S$ & SAH, Depression & L1-S1 & 3 & 3 & $\begin{array}{c}\text { Staphylococus Aureus + } \\
\text { Klebsiella Pneumoniae }\end{array}$ & $3 \mathrm{IV}$ & 6 \\
\hline 7 & $\mathrm{~F}$ & 63 & S & - & T3-L5 & 3 & 3 & Escherichia Coli & $3 \mathrm{IV}$ & 45 \\
\hline 8 & $\mathrm{~F}$ & 41 & $\mathrm{DS}+\mathrm{DH}$ & - & L3-L5 & 3 & 1 & Staphylococus Aureus & 2 IV & 41 \\
\hline 9 & $F$ & 60 & SS & - & L4-S1 & 2 & 1 & Staphylococus Aureus & $3 \mathrm{IV}$ & 70 \\
\hline 10 & $\mathrm{~F}$ & 66 & SS & $\mathrm{DM}$ & L2-L5 & 1 & 1 & Staphylococus Aureus & $3 \mathrm{IV} / 6 \mathrm{PO}$ & 64 \\
\hline 11 & $\mathrm{~F}$ & 54 & $\mathrm{DS}+\mathrm{DH}$ & - & L3-S1 & 2 & 1 & $\begin{array}{c}\text { Escherichia Coli }+ \\
\text { Enterococcus Faecalis }\end{array}$ & $3 \mathrm{IV} / 4 \mathrm{PO}$ & 63 \\
\hline 16 & $\mathrm{~F}$ & 60 & DS & Obesity, DM & L3-L5 & 1 & 1 & Staphylococus Aureus & 3 IV/4PO & 30 \\
\hline 17 & $\mathrm{~F}$ & 77 & $\mathrm{~S}$ & - & L2-S1 & 8 & 1 & Staphylococus Aureus & $4 \mathrm{IV} / 8 \mathrm{PO}$ & 24 \\
\hline 18 & $\mathrm{~F}$ & 72 & SS & Corticoid & L2-L5 & 3 & 1 & Staphylococus Aureus & $4 \mathrm{IV} / 8 \mathrm{PO}$ & 24 \\
\hline 19 & $\mathrm{~F}$ & 51 & SS & $\mathrm{DM}$ & L4-L5 & 1 & 1 & Staphylococus Aureus & $3 \mathrm{IV} / 4 \mathrm{PO}$ & 18 \\
\hline
\end{tabular}

$\mathrm{SS}=$ Spinal Stenosis; $\mathrm{S}=$ Scoliosis; $\mathrm{DS}=$ Degenerative Spondylolisthesis; $\mathrm{DH}=$ Discal Herniation; $\mathrm{DM}=$ Diabetes mellitus; $\mathrm{SAH}=$ Systemic Arterial Hypertension; IV= Intravenously; $\mathrm{PO}=$ Orally.

Table 2. Frequency of identified germs in subfascial fluid of patients with DWI.

\begin{tabular}{c|c|c}
\hline & Number of cases & C \\
\hline Staphylococus Aureus & $13 / 19$ & $68.4 \%$ \\
\hline Escherichia Coli & $5 / 19$ & $26.3 \%$ \\
\hline Corynebacterium & $1 / 19$ & $5.3 \%$ \\
\hline Klebsiella Pneumoniae & $1 / 19$ & $5.3 \%$ \\
\hline Enterobacter & $2 / 19$ & $10.5 \%$ \\
\hline Enterococcus Faecalis & $1 / 19$ & $5.3 \%$ \\
\hline
\end{tabular}

Table 3. Laboratorial parameters of patients treated for DWI at preoperative, 6 weeks postoperative and at the final evaluation

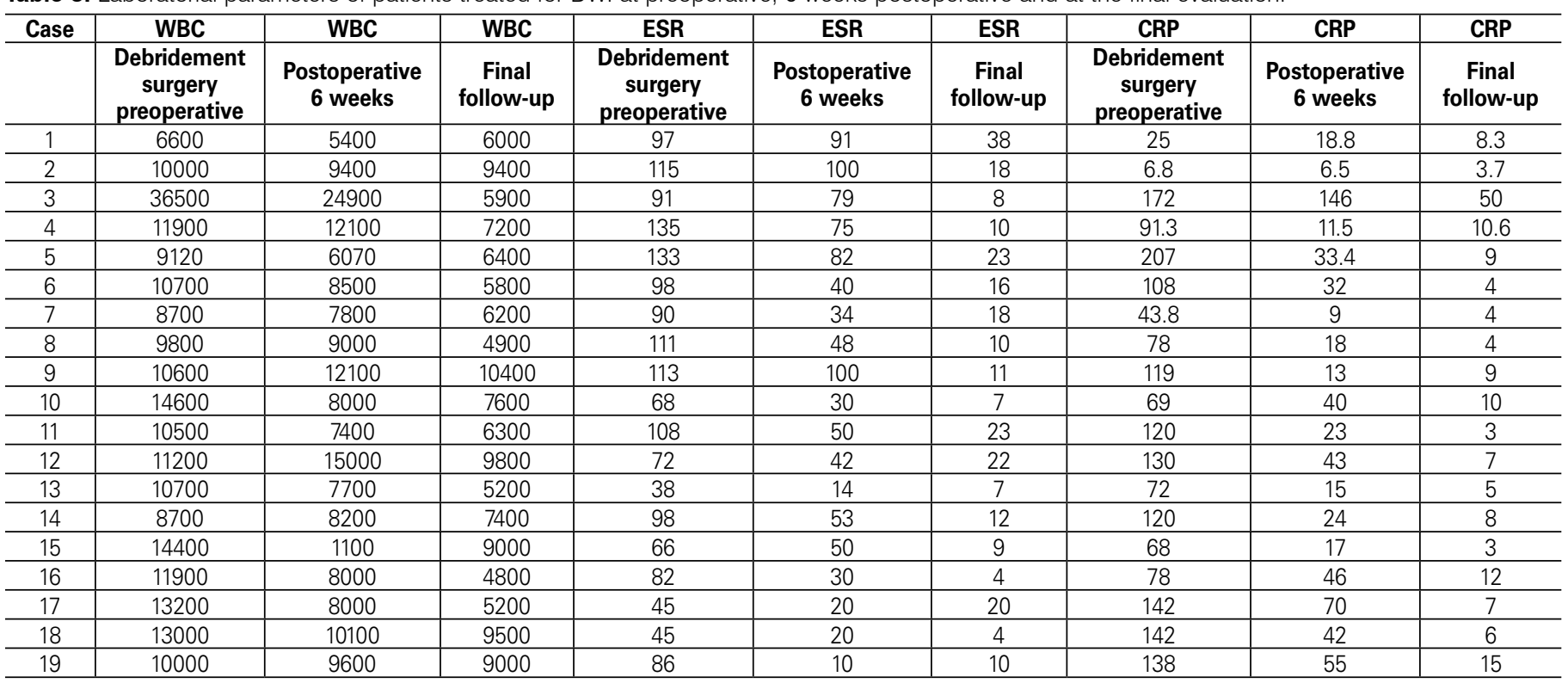

$\overline{\mathrm{WBC}}=$ White Blood Count; ESR $=$ Erythrocyte Sedimentation Rate; CRP $=$ C - Reactive Protein

predict the need for more than one debridement. (Table 4) According to these analyses the laboratory tests did not have the discrimination capacity to predict the need for more than one debridement. Also, there was no statistically significant difference in the mean of blood exams from pre-treatment and 6 weeks post-treatment between patients who underwent one debridement versus patients who underwent two or more reinterventions. (Table 5)
There was no displacement of the intervertebral device or breakage of the screw or rod at the final radiological examination. All patients have their spinal instrumented segments fused and without instability. The lumbar lordosis was higher during the short postoperative period, compared with the preoperative level. At the last evaluation there is a loss of $5 \pm 2.6$ grades of lumbar lordosis when compared with the early postoperative period. 


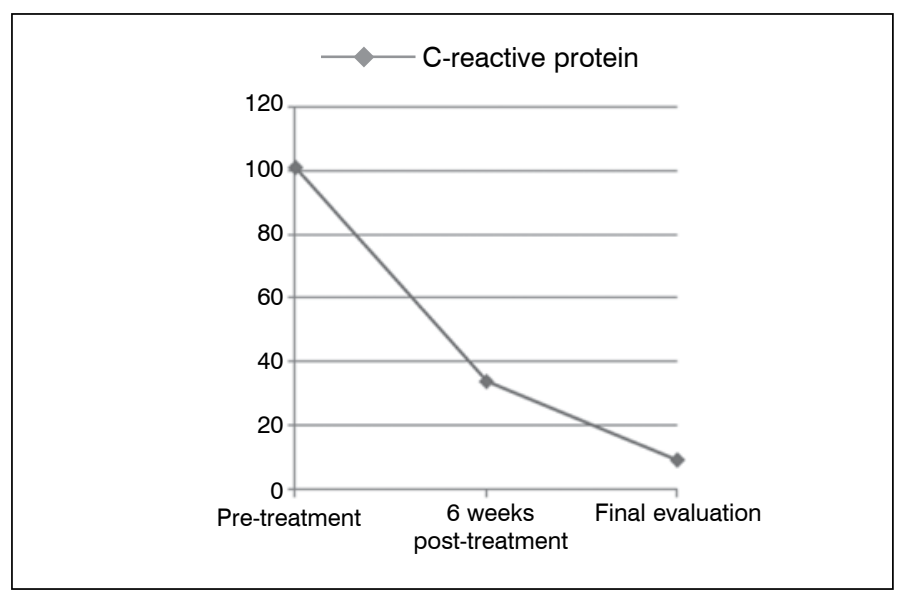

Figure 1. Evolution of C-reactive protein preoperatively, 6 weeks and final evolution.

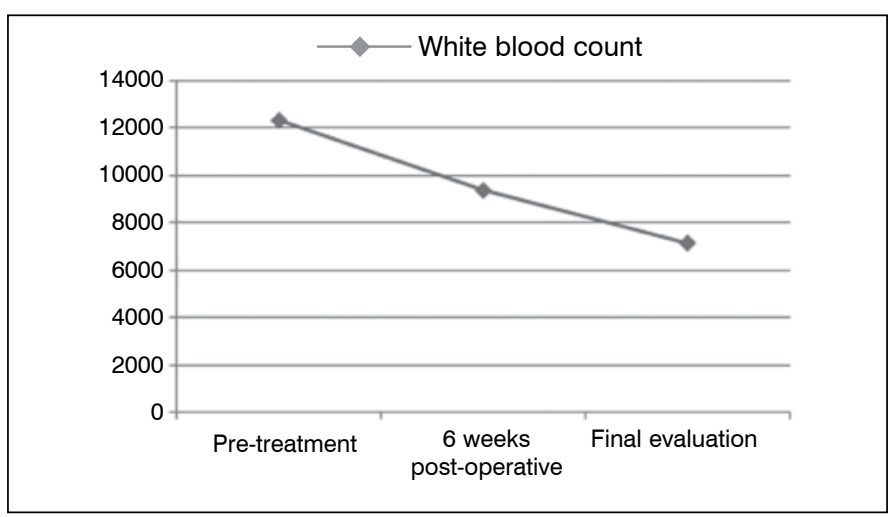

Figure 2. White blood count preoperatively, 6 weeks and final evolution.

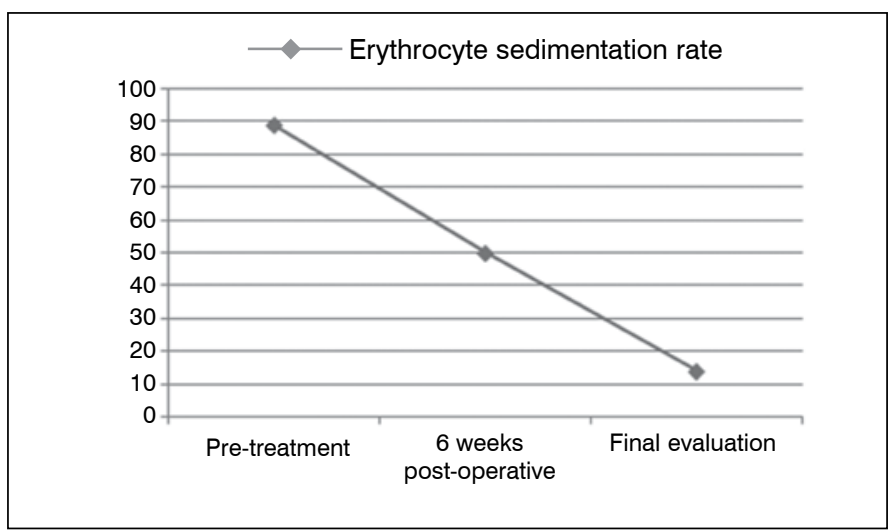

Figure 3. Evolution of erythrocyte sedimentation rate preoperatively, 6 weeks and final evolution.

\section{DISCUSSION}

DWI after lumbar spinal instrumented fusion results in a lower level of satisfaction, ${ }^{7}$ higher costs, ${ }^{10}$ further surgical interventions, ${ }^{2,4}$ higher morbidity, ${ }^{6}$ and may compromise the surgical outcome if not treated properly. ${ }^{2,7}$

Technological advances allow indicating surgery in patients with complex spinal disorders with a higher clinical morbidity while maintaining a good surgical outcome. ${ }^{5,20}$ However, there is an increased risk of complications such as DWI, 1,4,5,20 despite the prevention technics by using aseptic techniques and prophylactic antibiotics. ${ }^{1,21,22}$ In our series, the incidence of DWI was $4.87 \%$ in patients with lumbar degenerative disease who underwent posterior lumbar decompression and instrumented fusion.
Table 4. Demonstrates the results of calculated area under the ROC curve of variables.

\begin{tabular}{c|c|c|c}
\hline & Area & $\mathbf{9 5 \%} \mathbf{~ C l}$ & $\mathbf{p}$ \\
\hline Difference WBC (pre versus 6w) & 0.466 & $0.186-0.745$ & 0.804 \\
\hline Difference WBC (pre versus final) & 0.568 & $0.294-0.842$ & 0.620 \\
\hline Difference WBC (6w versus final) & 0.568 & $0.273-0.863$ & 0.620 \\
\hline Difference ESR (pre versus 6w) & 0.619 & $0.358-0.881$ & 0.881 \\
\hline Difference ESR (pre versus final) & 0.523 & $0.254-0.791$ & 0.791 \\
\hline Difference ESR (6w versus final) & 0.392 & $0.130-0.654$ & 0.654 \\
\hline Difference CRP (pre versus 6w) & 0.534 & $0.258-0.810$ & 0.804 \\
\hline Difference CRP (pre versus final) & 0.494 & $0.215-0.773$ & 0.967 \\
\hline Difference CRP (6w versus final) & 0.455 & $0.187-0.722$ & 0.741 \\
\hline WBC preoperative & 0.631 & $0.337-0.924$ & 0.342 \\
\hline ESR preoperative & 0.466 & $0.193-0.739$ & 0.804 \\
\hline CRP preoperative & 0.472 & $0.181-0.762$ & 0.836 \\
\hline
\end{tabular}

Table 5. Mean difference between pre-treatment and six weeks post-treatment in laboratory exams comparing one versus more than one debridement.

\begin{tabular}{c|c|c|c}
\hline & One debridement & $\begin{array}{c}\text { More than one } \\
\text { debridement }\end{array}$ & $\mathbf{p}$ \\
\hline White blood cell count & $2254.54(2456.97)$ & $3618.75(5828.12)$ & 0.549 \\
\hline Erythrocyte sedimentation rate & $40.81(21.79)$ & $34.25(20.96)$ & 0.519 \\
\hline C-reactive protein & $65.10(33.43)$ & $68.82(52.54)$ & 0.852 \\
\hline
\end{tabular}

The efficacy of the treatment of postoperative spinal infection is correlated with early diagnosis and aggressive management with surgical debridement, appropriate antibiotics and nutritional supplementation. ${ }^{1,23}$ There is a discussion about the efficacy of the closed irrigation system, the need for removing instrumentation and primary

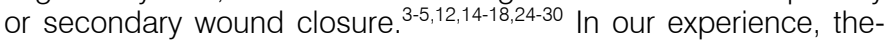
se patients can be successfully managed with aggressive surgical debridement combined with a closed irrigation system and primary wound closure without removing the instrumentation.

Rohmiller et al. ${ }^{12}$ in a retrospective study from 1990 to 2002 reported their management of 28 cases of DWI including the onset of acute and late wound infections. These patients were treated by debridement, antibiotics and a closed suction irrigation system during a varying period of time ranging from 1 to 15 days (mean 4 days). The irrigation system was used only once in $75 \%$ of cases and twice in the remaining cases. The closed drainage was used for only one day in seven patients (50\%), two days in two patients (14.28\%) and more than two days in five patients (35.72\%). The authors concluded that debridement, antibiotics and a closed suction irrigation system are an effective method to treat postoperative DWI. In our study, the patients have an acute DWI and the treatment was prompt extensive debridement, antibiotics and a closed irrigation system during 5 days that could be repeated by replacement of the drainage system. Using this protocol it was possible to treat the infections without removing the instrumentation or compromising the surgical goals.

In our cases the number of interventions was one debridement in 11 patients $(57.8 \%)$, two in three patients $(15.7 \%)$ and more than two in five patients $(26.3 \%)$. The cases where more than two debridements were needed to resolve the spinal infection, three interventions were necessary in three cases, four interventions in one case and five debridements in one case. In those cases, the reoperation was indicated because the values of PCR and VSG were being progressively reduced but not as normal values or positive cultures was observed in the irrigation system outflow fluid. The patient and his family were informed about the necessity to have the instrumentation removed in cases where the infection persisted. They decided that this therapy should be the last to be adopted since they have to pay again for the instrumentation to be replaced.

On the contrary of publications showing favorable results using the closed irrigation system for $\mathrm{DW} \mathrm{I}^{5,12,31}$ there are reports of increased risk of pseudarthrosis and pseudomonas superinfection. ${ }^{28}$

There are contradictory suggestions in the literature about the need to remove instrumentation after the diagnosis of DWI. Some publications advocated the removal of instrumentation for successful treatment of infection, 4,14,24,27,32 while others maintain the instrumen- 
tation in order to minimize the risk of pseudarthrosis and instability. $3,5,14,15,25,26,30,33$ Weinstein et al. ${ }^{30}$ support the idea that the instrumentation should not be removed in order to maintain the surgical goal. Theiss et al. ${ }^{33}$ pointed out that there was no evidence to suggest that spinal instrumentation inhibited the ability to treat spinal infection. Kim et al. ${ }^{4}$ reported good results for the resolution of the DWI after wide debridement, antibiotic therapy and implant removal, but the authors describe an increase in complications, such as pseudarthrosis, loss of intervertebral height and lordosis. We demonstrated that it is possible to have the infection treated with the instrumentation in place to achieve the goals of primary surgery. In our cases no displacement or breakage of the instrumented devices was observed, the surgical spinal segments were fused and the lumbar lordosis maintained. Besides, the instrumentation allows stabilizing the motion segment and, theoretically, decreases the inflammation and promotes bone healing. ${ }^{1,34}$

Early detection and prompt management of DWI are crucial to achieve a successful outcome. ${ }^{32,35}$ Many methods have been studied to perform the early detection of DWI, including plain radiographs, spinal biopsy, MR imaging, and laboratory tests. ${ }^{32,36}$ Mok et al. ${ }^{37}$ reported that the elevation or failure to decrease the levels of CRP had a sensitivity of $82 \%$, specificity of $48 \%$, positive predictive value of $41 \%$ and negative predictive value of $86 \%$ to detect or exclude DWI. Blood tests such as WBC, ESR and CRP are simple methods to identify and follow the course of WDI. ${ }^{32}$ In our experience, the time of onset of this complication occurs in two weeks postoperatively in the majority of patients. Whenever the patient has a history of lumbar pain, associated with abnormal laboratory tests of WBC, ESR, CRP, and presence of a fluid leakage from the skin, surgical debridement is mandatory to collect material to confirm or not the infection and at the same time to treat with extensive and aggressive debridement and washing.

Dipaola et al ${ }^{38}$ studied a series of 128 patients with DWI and reported that predictive factors of multiple irrigation and debridement were: positive methicillin-resistant Staphylococcus aureus culture, distant site infection, presence of instrumentation, location of surgery in the posterior lumbar spine, the use of non autograft bone graft material and the presence of diabetes mellitus. Mehta et al. ${ }^{39}$ suggested that in obese patients, the distribution of the body fat such as skin to lamina distance and thickness of the subcutaneous fat, is more predictive of DWI than absolute obesity. The laboratory parameters were used to follow the resolution of infection, but not as a parameter to predict the need for reinterventions. In our article, we could not find a laboratory test to predict the necessity for new interventions, only a relationship between the reduction of these parameters and infection resolution.

There is an ongoing multicenter study to increase the sample and achieve a greater level of evidence and statistical impact.

\section{CONCLUSION}

A protocol combining prompt surgical exploration, extensive washing, debridement of necrotic tissue, placement of a closed irrigation system for a period of five days and proper intravenous antibiotics therapy, was successfully used to treat a DWI in patients after instrumented posterior lumbar surgery without removal of the instrumentation. Six weeks after the treatment there was a decrease of WBC, ESR and CRP, however none of these laboratory tests are useful to predict the need for surgical reinterventions.

\section{ACKNOWLEDGMENTS}

We thank AOSpine Latin America for financial support of this study.

All authors declare no potential conflict of interest concerning this article.

\section{REFERENCES}

1. Beiner JM, Grauer J, Kwon BK, Vaccaro AR. Postoperative wound infections of the spine. Neurosurg Focus. 2003:15(3):E14.

2. Picada R, Winter RB, Lonstein JE, Denis F, Pinto MR, Smith MD, et al. Postoperative deep wound infection in adults after posterior lumbosacral spine fusion with instrumentation: incidence and management. J Spinal Disord. 2000;13(1):42-5

3. Jones GA, Butler J, Lieberman I, Schlenk R. Negative-pressure wound therapy in the treatment of complex postoperative spinal wound infections: complications and lessons learned using vacuum-assisted closure. J Neurosurg Spine 2007:6(5):407-11.

4. Kim JI, Suh KT, Kim SJ, Lee JS. Implant removal for the management of infection after instrumented spinal fusion. J Spinal Disord Tech. 2010;23(4):258-65.

5. Levi AD, Dickman CA, Sonntag VK. Management of postoperative infections after spinal instrumentation. J Neurosurg. 1997:86(6):975-80.

6. Mok JM, Guillaume TJ, Talu U, Berven SH, Deviren V, Kroeber M, et al. Clinical outcome of deep wound infection after instrumented posterior spinal fusion: a matched cohort analysis. Spine (Phila Pa 1976). 2009;34(6):578-83.

7. Calderone RR, Garland DE, Capen DA, Oster H. Cost of medical care for postoperative spinal infections. Orthop Clin North Am. 1996;27(1):171-82

8. Falavigna A, Righesso O, Traynelis VC, Teles AR, da Silva PG. Effect of deep wound infection following lumbar arthrodesis for degenerative disc disease on long-term outcome: a prospective study: clinical article. J Neurosurg Spine. 2011;15(4):399-403.

9. Calderone RR, Thomas JC Jr, Haye W, Abeles D. Outcome assessment in spinal infections. Orthop Clin North Am. 1996;27(1):201-5

10. Falavigna A, Righesso O, Teles AR, Kleber FD. Clinical and functional outcome of patients with deep wound infection after spinal lumbar fusion. Coluna/Columna. 2009;8(2):171-7.

11. Gruskay J, Kepler C, Smith J, Radcliff K, Vaccaro A. Is surgical case order associated with increased infection rate after spine surgery? Spine (Phila Pa 1976). 2012:37(13):1170-4.

12. Rohmiller MT, Akbarnia BA, Raiszadeh K, Raiszadeh K, Canale S. Closed suction irrigation for the treatment of postoperative wound infections following posterior spinal fusion and instrumentation. Spine (Phila Pa 1976). 2010;35(6):642-6.

13. Falavigna A, Righesso Neto O, Fonseca GP, Nervo M. Management of deep wound infections in spinal lumbar fusions. Arq Neuropsiquiatr. 2006:64(4):1001-4.

14. Hong HS, Chang MC, Liu CL, Chen TH. Is aggressive surgery necessary for acute postoperative deep spinal wound infection? Spine (Phila Pa 1976). 2008;33(22):2473-8.

15. Mirovsky Y, Floman Y, Smorgick Y, Ashkenazi E, Anekstein Y, Millgram MA, et al. Management of deep wound infection after posterior lumbar interbody fusion with cages. $J$ Spinal Disord Tech. 2007;20(2):127-31.

16. Chikawa T, Sakai T, Bhatia NN, Sairyo K, Utunomiya R, Nakamura M, et al. Retrospective study of deep surgical site infections following spinal surgery and the effectiveness of continuous irrigation. Br J Neurosurg. 2011:25(5):621-4.

17. Dubée V, Lenoir T, Leflon-Guibout V, Briere-Bellier C, Guigui P, Fantin B. Three-month antibiotic therapy for early-onset postoperative spinal implant infections. Clin Infect Dis. 2012;55(11):1481-7.

8. Ahmed R, Greenlee JD, Traynelis VC. Preservation of spinal instrumentation after development of postoperative bacterial infections in patients undergoing spinal arthrodesis. J Spinal Disord Tech. 2012:25(6):299-302.

19. Falavigna A, Righesso O, Teles AR. Clinical and functional evaluation in preoperative period of degenerative disease spine surgery. Coluna/Columna. 2009;8(3):234-53.

20. Fang A, Hu SS, Endres N, Bradford DS. Risk factors for infection after spinal surgery. Spine (Phila Pa 1976). 2005;30(12):1460-5

21. Barker FG 2nd. Efficacy of prophylactic antibiotic therapy in spinal surgery: a meta-analysis. Neurosurgery. 2002:51(2):391-400.

22. Cheng MT, Chang MC, Wang ST, Yu WK, Liu CL, Chen TH. Efficacy of dilute betadine solution irrigation in the prevention of postoperative infection of spinal surgery. Spine (Phila Pa 1976). 2005;30(15):1689-93.

23. Lonstein J, Winter R, Moe J, Gaines D. Wound infection with Harrington instrumentation and spine fusion for scoliosis. Clin Orthop Relat Res. 1973:(96):222-33.

24. Collins I, Wilson-MacDonald J, Chami G, Burgoyne W, Vineyakam P, Berendt T, et al. The diagnosis and management of infection following instrumented spinal fusion. Eur Spine J. 2008;17(3):445-50.

25. Glassman SD, Dimar JR, Puno RM, Johnson JR. Salvage of instrumental lumbar fusions complicated by surgical wound infection. Spine (Phila Pa 1976). 1996:21(18):2163-9.

26. Mehbod AA, Ogilvie JW, Pinto MR, Schwender JD, Transfeldt EE, Wood KB, et al. Postoperative deep wound infections in adults after spinal fusion: management with vacuumassisted wound closure. J Spinal Disord Tech. 2005;18(1):14-7.

27. Muschik M, Lück W, Schlenzka D. Implant removal for late-developing infection after instrumented posterior spinal fusion for scoliosis: reinstrumentation reduces loss of correction. A retrospective analysis of 45 cases. Eur Spine J. 2004:13(7):645-51.

28. Richards BS. Delayed infections following posterior spinal instrumentation for the treatment of idiopathic scoliosis. J Bone Joint Surg Am. 1995;77(4):524-9.

29. Vender JR, Hester S, Houle PJ, Choudhri HF, Rekito A, McDonnell DE. The use of closedsuction irrigation systems to manage spinal infections. J Neurosurg Spine. 2005:3(4):276-82.

30. Weinstein MA McCabe JP Cammisa FP Jr. Postoperative spinal wound infection: a review of 2,391 consecutive index procedures. J Spinal Disord. 2000;13(5):422-6.

31. Massie JB, Heller JG, Abitbol JJ, McPherson D, Garfin SR. Postoperative posterior spinal wound infections. Clin Orthop Relat Res. 1992;(284):99-108.

32. Kang BU, Lee SH, Ahn Y, Choi WC, Choi YG. Surgical site infection in spinal surgery: detection and management based on serial $\mathrm{C}$-reactive protein measurements. J Neurosurg Spine. 2010;13(2):158-64.

33. Theiss SM, Lonstein JE, Winter RB. Wound infections in reconstructive spine surgery. Orthop Clin North Am. 1996;27(1):105-10

34. Abbey DM, Turner DM, Warson JS, Wirt TC, Scalley RD. Treatment of postoperative wound infections following spinal fusion with instrumentation. J Spinal Disord. 1995:8(4):278-83.

35. Sasso RC, Garrido BJ. Postoperative spinal wound infections. J Am Acad Orthop Surg 2008;16(6):330-7.

36. Kornblum MB, Wesolowski DP, Fischgrund JS, Herkowitz HN. Computed tomographyguided biopsy of the spine. A review of 103 patients. Spine (Phila Pa 1976). 1998;23(1):81-5

37. Mok JM, Pekmezci M, Piper SL, Boyd E, Berven SH, Burch S, et al. Use of C-reactive protein after spinal surgery: comparison with erythrocyte sedimentation rate as predictor of early postoperative infectious complications. Spine (Phila Pa 1976). 2008;33(4):415-21.

38. Dipaola CP, Saravanja DD, Boriani L, Zhang H, Boyd MC, Kwon BK, et al. Postoperative infection treatment score for the spine (PITSS): construction and validation of a predictive model to define need for single versus multiple irrigation and debridement for spinal surgical site infection. Spine J. 2012:12(3):218-30.

39. Mehta Al, Babu R, Karikari IO, Grunch B, Agarwal VJ, Owens TR, et al. 2012 Young Investigator Award winner: The distribution of body mass as a significant risk factor for lumbar spinal fusion postoperative infections. Spine (Phila Pa 1976). 2012;37(19):1652-6. 